\title{
Studies on high pressure-high temperature synthesis of carbon clathrates
}

\author{
Badania nad wysokociśnieniowo-wysokotemperaturową \\ syntezą klatratów węglowych
}

\author{
JULIUSZ LESZCZYŃSKI \\ PIOTR KLIMCZYK \\ KRZYSZTOF WOJCIECHOWSKI \\ ANDRZEJ KOLEŻYŃSKI *
}

\author{
DOI: $10.17814 /$ mechanik.2016.5-6.62 \\ Międzynarodowa Konferencja IMT 2016
}

\begin{abstract}
Ab initio DFT calculations were used for theoretical analysis of crystal and electronic structure of $\mathrm{C}_{46}, \mathrm{Li}_{8} \mathrm{C}_{46}$ and $\mathrm{Li}_{8} \mathrm{~B}_{6} \mathrm{C}_{40}$ carbon clathrates. Simultaneously experimental attempts of carbon clathrates synthesis from fullerene $\mathrm{C}_{60}$ at pressure $8 \mathrm{GPa}$ were made. For a specific conditions polymerized form of fullerene - fullerite was obtained.
\end{abstract}

KEYWORDS: carbon clathrate, band structure calculations, HPHT synthesis, fullerene, fullerite

Przeprowadzono obliczenia ab initio metodą DFT w celu analizy struktury krystalicznej i elektronowej hipotetycznych klatratów węglowych $\mathrm{C}_{46}, \mathrm{Li}_{8} \mathrm{C}_{46}$ i $\mathrm{Li}_{8} \mathrm{~B}_{6} \mathrm{C}_{40}$. Jednocześnie podjęto próby syntezy klatratów węglowych z fullerenu $C_{60}$ pod ciśnieniem $8 \mathrm{GPa}$. W pewnych warunkach otrzymano spolimeryzowaną formę fullerenu - fulleryt.

SŁOWA KLUCZOWE: klatraty węglowe, obliczenia struktury pasmowej, HPHT, fulleren, fulleryt

Theoretically predicted carbon clathrates are analogs of a very fascinating group of cage compounds usually called intermetallic clathrates. Structural framework of these compounds is formed by $\mathrm{Si}, \mathrm{Ge}$ and $\mathrm{Sn}$ atoms, which for the type-I clathrate structure are arranged into uniformly space filling dodecahedrons $X_{20}$ and tetrakaidecahedrons $X_{24}$. The empty space inside these polyhedra is a structural cage that can be filled by atoms like alkali and alkaline earth metals. For the type-I structure (space group $P m-3 n$ ) presented in the Fig. 1 , the unit cell formula is $\mathrm{Me}_{8} \mathrm{X}_{46}$, where $\mathrm{Me}$ is the metal inside the cage and $X$ is the framework atom. Due to their structural features, clathrates are familiar to fullerenes and carbon nanotubes. Intermetallic clathrates gained recently much interest for their promising thermoelectric properties. Although, there are known numerous silicon, germanium and tin clathrates [1] the analogous carbon compounds have never been synthesized. So far only detailed theoretical calculations of structural, electronic and vibrational properties of carbon clathrates have been performed by both tight-binding and ab-initio methods $[2 \div 5]$. Theoretical predictions point out that the carbon clathrates should show unusual combination of properties. Hypothetic carbon clathrate should be the one of hardest materials after diamond and lonsdaleite [2] and $\mathrm{C}_{46}$ should have a high bulk modulus, just $15 \%$ smaller than that of diamond, with an outstanding shear modulus, greater than that of diamond by at least $25 \%[2,5]$. The results of numerical calculations

\footnotetext{
*Dr inż. Juliusz Leszczyński (Juliusz.Leszczynski@agh.edu.pl), prof. dr hab. inż. Krzysztof Wojciechowski (wojciech@agh.edu.pl), dr hab. inż. Andrzej Koleżyński (kolezyn@agh.edu.pl) - Wydział Inżynierii Materiałowej i Ceramiki, Akademia Górniczo-Hutnicza; dr inż. Piotr Klimczyk (piotr.klimczyk@ios.krakow.pl) - Instytut Zaawansowanych Technologii Wytwarzania
}

indicates that high pressure-high temperature conditions are necessary to reach the thermodynamic stability range of the predicted new compounds. The aim of this work was to use high pressure-high temperature conditions for synthesis of carbon type-I clathrates coupled with theoretical calculations for prediction of structural and electronic properties of the hypothetical compounds.

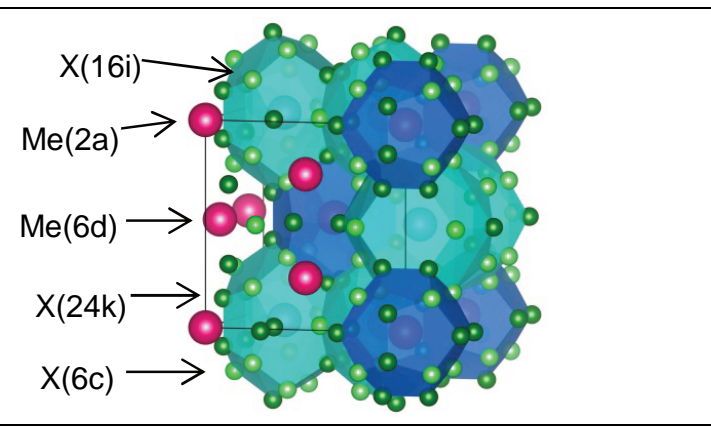

Fig. 1. Unit cell of the type-I clathrate structure with marked structural polyhedra. The Wyckoff positions of the atoms are given in parentheses

\section{Experimental details}

Several tries of carbon clathrate synthesis through reaction of $\mathrm{C}_{60}$ with $\mathrm{Li}$ were carried out using HPHT method. Prior that behavior of $\mathrm{C}_{60}$ under high temperature and high pressure was examined. Detailed data on experiments conditions are presented in the table. The samples were synthesized at pressure of $7.7 \mathrm{GPa}$ in the temperature range of $770 \div 2270 \mathrm{~K}$ using a Bridgman-type toroid high-pressure apparatus. Pure fullerene $\mathrm{C}_{60}$ (CheapTubes Inc. 98\%) or stoichiometric mixture of Li (99.9\% Alfa Aesar Li foil) and $\mathrm{C}_{60}$ were loaded into $\mathrm{Nb}$ capsules $(\varnothing=15 \mathrm{~mm})$ in an Ar-filled glove box.

\section{TABLE. Conditions of the HPHT experiments}

\begin{tabular}{|c|c|c|c|}
\hline Sample name & Pressure, $\mathrm{GPa}$ & Temperature, $\mathrm{K}$ & Time, $\mathrm{s}$ \\
\hline $\mathrm{C}_{60} 2$ & 7.7 & 2260 & 60 \\
\hline $\mathrm{C}_{60} 3$ & 7.7 & 1740 & 60 \\
\hline $\mathrm{C}_{60} 5$ & 7.7 & 1170 & 600 \\
\hline $\mathrm{C}_{60} 6$ & 7.7 & 770 & 600 \\
\hline $\mathrm{Li}_{8} \mathrm{C}_{46} 1$ & 7.7 & 1730 & 60 \\
\hline $\mathrm{Li}_{8} \mathrm{C}_{46} 2$ & 7.7 & 2190 & 60 \\
\hline
\end{tabular}

Next, the enclosed $\mathrm{Nb}$ containers were placed in a graphite heater fitted to a high pressure gasket made of a block of lithographic stone. The heater with the capsule inside was placed in the high pressure cell and the required pressure and temperature was applied. After that the sample was removed from the capsule. Some part of the sample was 
ground into powder in an agate mortar for x-ray diffractometric XRD measurements. In case of Li containing samples these steps were performed in the glove-box and the obtained powder for the XRD measurement was loaded into glass capillary, which was tightly welded. XRD measurements were carried out using PANalytical Empyrean apparatus, with $\mathrm{CuK}_{\alpha}$ radiation.

First principles calculations for $\mathrm{C}_{46}, \mathrm{Li}_{8} \mathrm{C}_{46}, \mathrm{Li}_{8} \mathrm{~B}_{6} \mathrm{C}_{40}$, have been performed using WIEN2k FP-LAPW ab initio package [6] within density functional theory DFT formalism. 250 $k$-points $(6 \times 6 \times 6 k$-mesh points within the irreducible Brillouin zone), cut-off parameter $R k_{\max }=7.5$ and Perdew-Burke-Ernzerhof optimized for solids (GGA-PBE Sol) exchange-correlation potential have been chosen for calculations. More details can be found elsewhere [7]. As the initial data, the cell parameters and fractional atomic coordinates were taken from crystal structure for $\mathrm{Ba}_{8} \mathrm{Ga}_{16} \mathrm{Ge}_{30}$ and then cell parameters and atomic positions of all the structures were optimized. Based on the literature data, B substitution for $C$ was assumed to occur in $6 \mathrm{c}$ site, and the $\mathrm{Li}_{8} \mathrm{~B}_{6} \mathrm{C}_{40} \mathrm{com}$ pound corresponds to complete replacement of carbon in the $6 \mathrm{c}$ site. As a result density of states DOS of the selected structures was calculated.

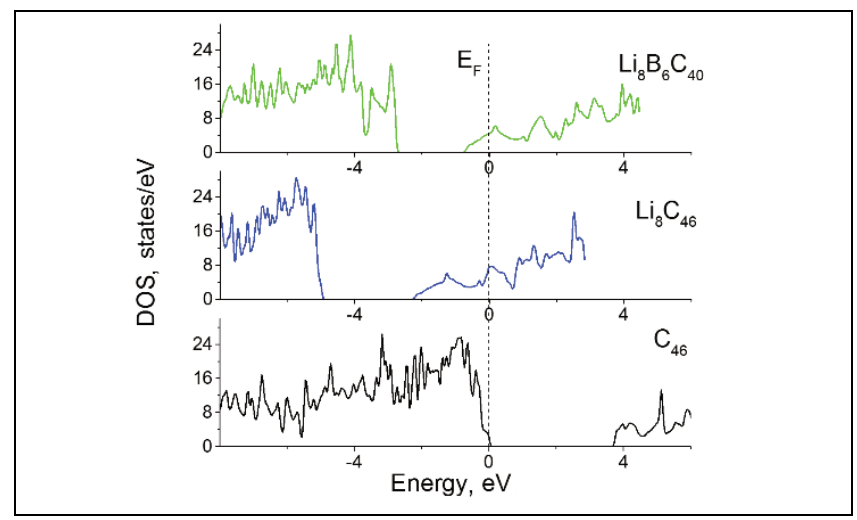

Fig. 2. Densities of states DOS obtained from DFT calculations

\section{Results}

For all of the examined structures, calculations converged to stable solutions within the type-I clathrate structure. The calculated total DOS for $\mathrm{C}_{46}, \mathrm{Li}_{8} \mathrm{C}_{46}, \mathrm{Li}_{8} \mathrm{~B}_{6} \mathrm{C}_{40}$ are presented in Fig. 2. For pure carbon clathrate $\mathrm{C}_{46}$ the Fermi level is located at the top of the valence band, in agreement with previous GW results [5]. The calculated lattice parameter $6.6725 \AA$ is also in quite good agreement with earlier findings [4], however, it is a little bit lower $(6.69 \div 6.72 \AA)$ compared to results obtained using VASP and DMOL software. Filling of the structural voids by Li lifts the Fermi energy to the conduction band, as the lithium acts as the donor of electrons. This implies that the $\mathrm{Li}_{8} \mathrm{C}_{46}$ should be $n$-type semiconductor. The lattice constant increases to $6.8003 \AA$. Substitution of $\mathrm{C}$ by boron, with one valence electron less, pulls the Fermi level down as the boron is electron acceptor in this system. This also decrease the overall energy and should increase the structure stability. The benefit of the guest atom use - e.g. $\mathrm{Li}$, in carbon clathrate synthesis is that it would act as a template for carbon cage formation like it is done in $\mathrm{Si}, \mathrm{Ge}$ and $\mathrm{Sn}$ clathrates synthesis.

The samples obtained from HPHT experiments in most cases were cracked into several pieces. They were black and brownish-black. Results of the XRD analysis of these samples are presented in Fig. 3. A diffraction pattern of the initial $\mathrm{C}_{60}$ is also shown for comparison. All of the obtained diffractograms are characterized by huge reflection broadening which can be result of either small crystallite size or strain and structural imperfections. Under HPHT conditions fullerene $\mathrm{C}_{60}$ undergoes transition to graphite. At lower temperatures $(<800 \mathrm{~K})$ under pressure of several $\mathrm{GPa} \mathrm{C}_{60}$ can be transformed into several forms of fullerites [8]. This was observed for sample $\mathrm{C}_{60} 6$, which was probably partly transformed to two different fullerite structures. An unambiguous determination of these structures is unfortunately impossible due to strong overlapping and asymmetry of reflections. In case of samples obtained by HPHT reaction of lithium and fullerene the main product was graphite. Unfortunately, most of the $\mathrm{Li}$ reacted with oxygen and water forming $\mathrm{LiOH}$. Small amount of lithium carbide $\mathrm{Li}_{2} \mathrm{C}_{2}$ was also detected.

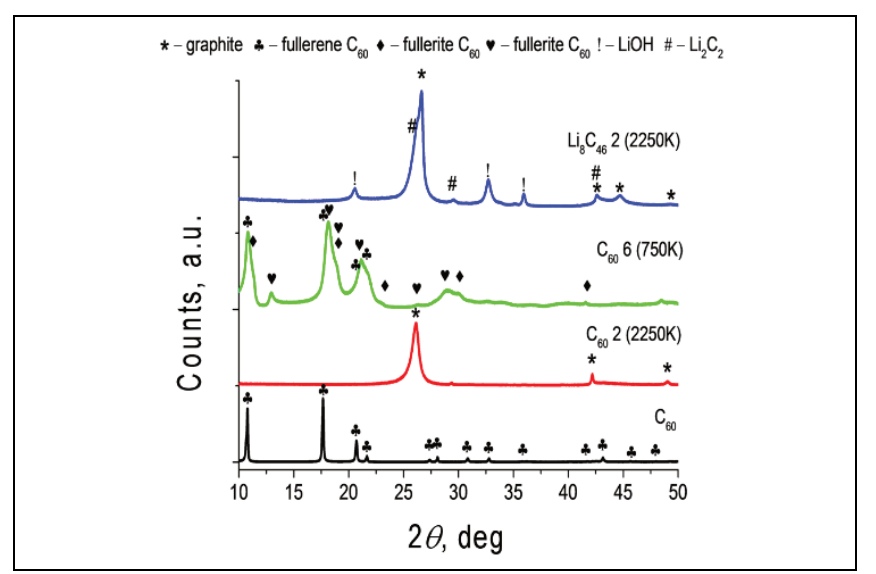

Fig. 3. XRD results of selected representative samples

These result points out that more attention must be paid on sample protection against oxidation during all of the synthesis steps.

\section{Summary}

First principle calculations show that carbon clathrates can be metastable compounds with semiconducting properties, depending on their composition. Use of Li filling the structural voids together with B substitution for C should facilitate synthesis of these hypothetical compounds. In moderately high temperature-high pressure conditions it was possible to partly transform fullerene into polymerized form of fullerite. Addition of $\mathrm{Li}$ to $\mathrm{C}_{60}$ in this conditions can result in synthesis of a $\mathrm{Li}-\mathrm{C}$ compound with cage structure, but better protection against oxidation is necessary.

The work was supported by the Polish Ministry of Higher Education, statutory research grant 2013/09/B/ST8/02043. The band structure calculations were supported in part by Pl-Grid infrastructure.

\section{LITERATURE}

1. Christensen M., Johnsen S., Iversen B.B. „Thermoelectric clathrates of type I". Dalton Transactions. Vol. 39 (2010): pp.

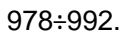

2. Perottoni A., Jornada J. A. H. „The carbon analogues of type-I silicon clathrates". J. of Phyics: Condensed Matter. Vol. 13, No.

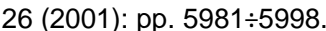

3. Wang J.-T., Chen C., Wang D.-S., Mizuseki H., Kawazoe Y. „Phase stability of carbon clathrates at high pressure”. Journal of Applied Physics. Vol. 107, No. 6 (2010): p. 063507.

4. Connetable D., Blasé X. „Electronic and superconducting properties of silicon and carbon clathrates". Appl. Surf. Sci. Vol. 226, No. $1 \div 3$ (2004): pp. $289 \div 297$

5. Blase X., Gillet P., San Miguel A., Melinon P. „Exceptional Ideal Strength of Carbon Clathrates". Phys. Rev. Lett. Vol. 92, No. 21 (2004): p. 215505.

6. Blaha P., Schwarz K., Madsen G.K.H., Kvasnicka D., Luitz J. WIEN2k, An Augmented Plane Wave + Local Orbitals Program for Calculating Crystal Properties. Wien: Karlheinz Schwarz, Techn. Universität Wien, 2001

7. Koleżyński A., Szczypka W. DOI: 10.1007/s11664-015-4028-6.

8. Yamanaka S. "Silicon clathrates and carbon analogs: high pressure synthesis, structure, and superconductivity". Dalton Trans-

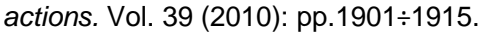

